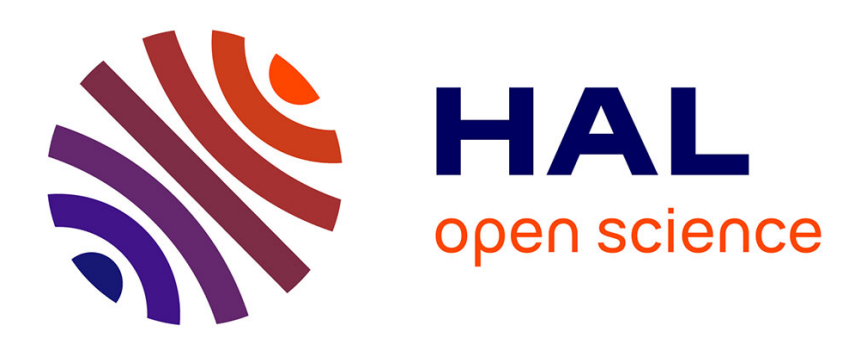

\title{
A variable streamflow velocity method for global river routing model: model description and preliminary results
}

\author{
T. Ngo-Duc, T. Oki, S. Kanae
}

\section{- To cite this version:}

T. Ngo-Duc, T. Oki, S. Kanae. A variable streamflow velocity method for global river routing model: model description and preliminary results. Hydrology and Earth System Sciences Discussions, 2007, 4 (6), pp.4389-4414. hal-00298918

\section{HAL Id: hal-00298918 \\ https://hal.science/hal-00298918}

Submitted on 13 Dec 2007

HAL is a multi-disciplinary open access archive for the deposit and dissemination of scientific research documents, whether they are published or not. The documents may come from teaching and research institutions in France or abroad, or from public or private research centers.
L'archive ouverte pluridisciplinaire HAL, est destinée au dépôt et à la diffusion de documents scientifiques de niveau recherche, publiés ou non, émanant des établissements d'enseignement et de recherche français ou étrangers, des laboratoires publics ou privés. 
Hydrol. Earth Syst. Sci. Discuss., 4, 4389-4414, 2007 www.hydrol-earth-syst-sci-discuss.net/4/4389/2007/

(C) Author(s) 2007. This work is licensed under a Creative Commons License.
Hydrology and Earth System Sciences Discussions

Papers published in Hydrology and Earth System Sciences Discussions are under open-access review for the journal Hydrology and Earth System Sciences

\section{A variable streamflow velocity method for global river routing model: model description and preliminary results}

T. Ngo-Duc, T. Oki, and S. Kanae

Institute of Industrial Science, University of Tokyo, Japan

Received: 13 November 2007 - Accepted: 21 November 2007 - Published: 13 December 2007

Correspondence to: T. Ngo-Duc (thanh @ rainbow.iis.u-tokyo.ac.jp)

\section{HESSD}

4, 4389-4414, 2007

A variable velocity method for global river routing model

T. Ngo-Duc et al.

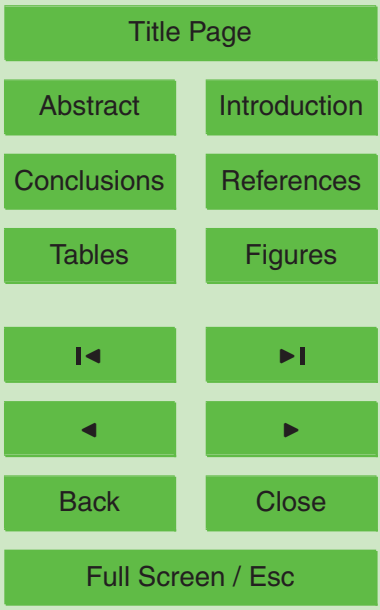

Printer-friendly Version

Interactive Discussion 


\section{Abstract}

This paper presents an attempt of simulating daily fluctuations of river discharge at global scale. Total Runoff Integrating Pathways (TRIP) is a global river routing model which can help to isolate the river basins, inter-basin transport of water through river 5 channels, as well as collect and route runoff to the river mouths for all the major rivers. In the previous version of TRIP (TRIP 1.0), a simple approach of constant river flow velocity is used. In general, that approach is sufficient to model mean long-term discharges. However, to model short-term fluctuations, more sophisticated approach is required. In this study, we implement a variable streamflow velocity method to TRIP

10 (TRIP 2.0) and validate the new approach over the world's 20 major rivers. Two numerical experiments, one with the TRIP 1.0 and another with TRIP 2.0 are performed. Input runoff is taken from the multi-model product provided by the second Global Soil Wetness Project. For the rivers which have clear daily fluctuations of river discharge, TRIP 2.0 shows advantages over TRIP 1.0, suggesting that TRIP 2.0 can be used to 15 model flood events.

\section{Introduction}

Understanding the movement of water over the earth's surface has long been a fascinating research target. Many hydrologic studies have been done to determine the quantity of flow along rivers at various points in time and space. Most of these studies have focused on small watersheds. Recently with the technology development and the concerns about global climate change, the climate modeling community has focused attention on the need for routing models to track the flow of water from continents to oceans at global scale.

Several advantages of routing models can be listed here. First, routing runoff pro-
HESSD

4, 4389-4414, 2007

A variable velocity method for global river routing model

T. Ngo-Duc et al.

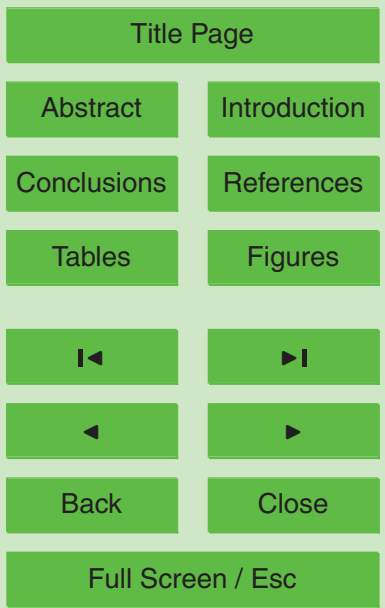

Printer-friendly Version

Interactive Discussion drograph data. As most variables describing the state of the surface are not directly 
observable, river discharge is an appropriate measure to assess model qualities. Second, the simulated fresh water flux into the oceans alters their salinity and may affect the thermohaline circulation (e.g. Wang et al., 1999; Wijffels et al., 1992). Third, estimates of river discharge from climate change simulations can also be used to assess 5 the impact of climate change on water resources and the hydrology of the major river basins (e.g. Arora and Boer, 2001; Milly et al., 2005; Oki and Kanae, 2006). Approaches for routing water through large-scale systems are thus evolving in response to the modeling needs.

In state-of-the-art global routing models, most of the approaches either assume a 10 constant velocity (e.g. Miller et al., 1994; Coe, 1998; Oki et al., 1998) or use simple formulae that use time-independent flow velocities parameterized as a function of the topographic gradient (Miller et al., 1994; Hagemann and Dümennil, 1996; Ducharne et al., 2003). In general, these approaches are sufficient to model discharges in monthly or longer time scales. However, to model in shorter temporal scales, more sophis15 ticated approach is required. Arora and Boer (1999) and more recently, Schulze et al. (2005) use the Manning's equation to determine time-evolving flow velocities as a function of discharge, river cross-section and channel slope:

$v=n^{-1} \times R^{2 / 3} \times s^{1 / 2}$

where $v$ is the flow velocity [m/s], $n$ is the Manning roughness coefficient [-], $R$ is the 20 hydraulic radius $[\mathrm{m}]$, and $s$ is the channel slope $[\mathrm{m} / \mathrm{m}]$. In their studies, the Manning roughness coefficient $n$ is supposed to be constant globally (Arora and Boer, 1999) or determined by tuning (Schulze et al., 2005). Since values of $n$ vary between 0.015 and 0.07 in natural streams for flows less than bankfull discharge and reach up to 0.25 for overbank flow (Fread, 1993), the assumption of a global constant roughness coefficient or the tuning method would contain limitations.

Dingman and Sharma (1997) developed the following relation from objective statistical analysis of over 500 in-bank flows:

$Q=1.564 \times A^{1.173} \times R^{0.400} \times S^{-0.0543 \times \log _{10} s}$
HESSD

4, 4389-4414, 2007

\section{A variable velocity method for global river routing model}

T. Ngo-Duc et al.

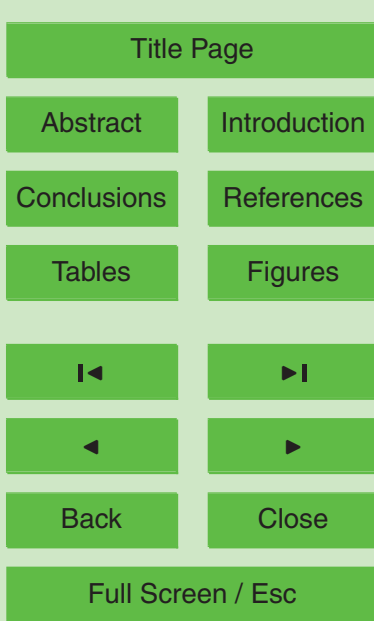

Printer-friendly Version

Interactive Discussion 
where $Q\left[\mathrm{~m}^{3} / \mathrm{s}\right]$ and $A\left[\mathrm{~m}^{2}\right]$ are river discharge and cross-sectional area respectively. Note that:

$Q=A \times V$

We can induce that Eq. (2) is another representation of the Manning equation (Eq. 1) 5 with the roughness coefficient calculated by:

$n=\frac{1}{1.564} \times A^{-0.173} \times R^{0.267} \times S^{0.5+0.0543 \times \log _{10} s}$

Thus, Eq. (2) proposed by Dingman and Sharma has potential to overcome the limitations of constant roughness coefficient assumption or a tuning procedure for global routing models.

Total Runoff Integrating Pathways (TRIP) is a global river routing model which can help to isolate the river basins, inter-basin tranport of water through river channels, as well as collect and route runoff to the river mouths for all the major rivers (Oki and Sud, 1998). In the previous version of TRIP (hereafter TRIP 1.0), the simple approach of constant river flow velocity was used. In this paper, we implement the Dingman and

15 Sharma equation to TRIP (hereafter TRIP 2.0) and perform the validation of the new approach over the Mekong and some other world's largest rivers.

\section{Methodology}

In TRIP 2.0, we define two water reservoirs: groundwater reservoir and surface water reservoir. Groundwater is represented by a simple linear reservoir (e.g. Maidment, 20 1993):

$\frac{d S_{g}}{d t}=D_{\mathrm{LSMg}}-D_{\mathrm{OUTg}}$
HESSD

4, 4389-4414, 2007

A variable velocity method for global river routing model

T. Ngo-Duc et al.

Title Page

Abstract

Introduction

Conclusions

References

Tables

Figures

14

$\rightarrow$

4

Back

Close

Full Screen / Esc

Printer-friendly Version

Interactive Discussion 
where $S_{g}\left[\mathrm{~m}^{3}\right], D_{\text {LSMg }}\left[\mathrm{m}^{3} / \mathrm{s}\right]$, and $D_{\text {OUTg }}\left[\mathrm{m}^{3} / \mathrm{s}\right]$ are groundwater storage, input subsurface runoff (obtained from the output of Land Surface Model (LSM)), and the outflow from the groundwater reservoir, respectively. The outflow is parameterized as:

$D_{\text {OUTg }}=\frac{1}{T_{g}} \times S_{g}$

5 where $T_{g}$ is a groundwater delay parameter expressed in days.

From Eq. (5) and Eq. (6), we obtain the solution for $S_{g}$ :

$S_{g}(t+d t)=e^{-d t / T_{g}} \times S_{g}(t)+\left(1-e^{-d t / T_{g}}\right) \times T_{g} \times D_{\mathrm{LSMg}}(t+d t)$

If $T_{g}=0$, we define $S_{g}=0, D_{\text {OUTg }}=D_{\text {LSMg }}$, i.e. TRIP 2.0 will route the total runoff and not separate anymore surface runoff and subsurface runoff.

10 The water balance within a grid cell for the surface water reservoir storage, $S_{S}\left[\mathrm{~m}^{3}\right]$, is given by:

$\frac{d S_{s}}{d t}=D_{\text {up }}+D_{\text {OUTg }}+D_{\text {LSMs }}-Q$

where $D_{\text {up }}\left[\mathrm{m}^{3} / \mathrm{s}\right]$ and $D_{\text {LSMs }}\left[\mathrm{m}^{3} / \mathrm{s}\right]$ are total inflow from upstream grid boxes and surface runoff calculated by LSM, respectively.

$S_{S}=A \times 1 \times r_{M}$

where / is the straight length of the river channel within the grid box calculated geometrically and $r_{M}$ is the meandering ratio (Oki and Sud, 1998) adjusting the river length to be realistic. In this study, we set $r_{M}=1.4$ globally.

20 Substituting Eq. (3), Eq. (9) into the continuity equation Eq. (8) yields:

$\frac{d S_{s}}{d t}=D_{\text {up }}+D_{\text {OUTg }}+D_{\text {LSMs }}-\frac{v}{1 \times r_{M}} \times S_{s}$

HESSD

4, 4389-4414, 2007

A variable velocity method for global river routing model

T. Ngo-Duc et al.

Title Page

Abstract

Introduction

Conclusions

References

Tables

Figures

14

$\rightarrow 1$

4

Back

Close

Full Screen / Esc

Printer-friendly Version

Interactive Discussion 
One should note that $v$ depends itself on $S_{s}$. To solve Eq. (10), we assume that $v$ is constant during each time step.

We obtain thus the solution of Eq. (10)

HESSD

4, 4389-4414, 2007

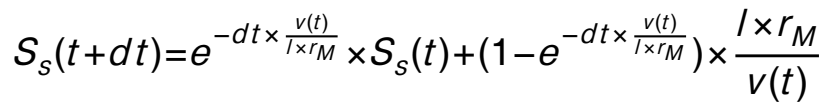

$$
\times\left(D_{\text {up }}(t+d t)+D_{\text {OUTg }}(t+d t)+D_{\text {LSMs }}(t+d t)\right)
$$

where $v(t)$ is calculated in the time step $t$ as followings:

From Eq. (2), Eq. (3), $v$ can be described as:

$v=1.564 \times A^{0.173} \times R^{0.400} \times S^{-0.0543 \times \log _{10} s}$

Assuming the river channel is shaped as a rectangle of width $W[\mathrm{~m}]$ and depth $h[\mathrm{~m}]$, thus we have:

$R=\frac{h \times W}{2 \times h+W}$

$W$ is obtained using a geomorphological relationship with annual mean discharge $Q_{m}$ $\left[\mathrm{m}^{3} \mathrm{~s}^{-1}\right]$ proposed by Arora and Boer (1999):

$W=\max \left(10,\left(6.0+10^{-4} \times Q_{\mathrm{m} . \text { mouth }}\right) \times Q_{m}^{0.5}\right)$

15 where $Q_{\mathrm{m} \text {.mouth }}\left[\mathrm{m}^{3} \mathrm{~s}^{-1}\right]$ is the annual mean discharge at the river mouth. Sensitivity of flow velocity to river width has shown that an error of $100 \%$ in the prescribed river width results in a corresponding error of about $25 \%$ in flow velocity (Arora and Boer, 1999). $Q_{m}$ is initially calculated from TRIP 1.0 , the constant velocity version of TRIP.

Eq. (12) thus becomes:

$20 \quad v=1.564 \times s^{-0.0543 \times \log _{10} s} \times \frac{S_{s}^{0.573}}{\left(/ \times r_{M}\right)^{0.573} \times\left(\frac{2 \times S_{s}}{/ \times r_{M} \times W}+W\right)^{0.400}}$

A variable velocity method for global river routing model

T. Ngo-Duc et al.

Title Page

Abstract

Introduction

Conclusions

References

Tables

Figures

14

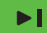

4

Back

Close

Full Screen / Esc

Printer-friendly Version

Interactive Discussion 


\section{Experiments design}

\subsection{Input runoff forcing}

The second Global Soil Wetness Project (GSWP2) (International GEWEX Project Office, 2002; Dirmeyer et al., 2006) is an ongoing environmental modeling research ac-

5 tivity aiming at producing global estimates of soil moisture, temperature, snow water equivalent, and surface fluxes by integrating one-way uncoupled LSMs using externally specified surface forcing and standardized soil vegetation distributions. In May 2005, 15 institutes from five nations have submitted their baseline run, and model ensemble mean (or simple arithmetic average of outputs among models) of surface fluxes 10 and state variable have been produced using 13 models (Dirmeyer et al., 2006). Gao and Dirmeyer (2006) compared the products (GSWP2-Multi Model Analysis, hereafter GSWP2-MMA) with in-situ soil moisture observation from the Global Soil Moisture Data Bank (Robock et al., 2002) and found that GSWP2-MMA is better than the best individual model at any location in the representation of both soil wetness and its anomaly.

The GSWP2-MMA data, as well as the data submitted by the participating modeling groups conform to the Assistance for Land-surface Modelling Activities convention (ALMA) (Polcher et al., 2000). The data has 1 degree by 1 degree (longitude-latitude) spatial resolution, and daily temporal resolution spanning the years 1986-1995.

All models (and GSWP2-MMA) provide two runoff variables: surface runoff and sub20 surface runoff. However, the partition of runoff into surface and subsurface varies significantly between models. Thus in this study, TRIP 2.0 is used to route total runoff from GSWP2-MMA on a digital river network map with a spatial resolution of 1 degree longitude by 1 degree latitude.

\subsection{Numerical experiments}

25 Two numerical experiments are performed. The first one, called T1 is obtained with the TRIP 1.0 version which used the constant velocity approach. In T1, the stream flow

\section{A variable velocity method for global river routing model}

T. Ngo-Duc et al.

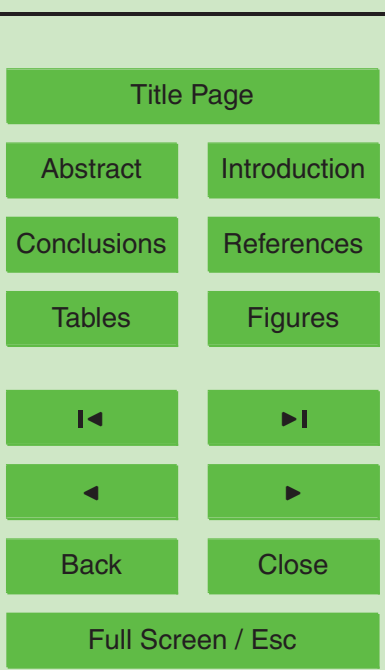

Printer-friendly Version

Interactive Discussion 
velocity is assumed constant and uniform at $0.5 \mathrm{~m} \mathrm{~s}^{-1}$ (e.g. Decharme and Douville, 2007; Oki and Sud., 1998). The second one, called T2 is obtained with TRIP 2.0 which used the new variable velocity approach. Both simulations use the GSWP2-MMA runoff of 1986 for spin-up (Fig. 1). Water storage in the river channels is initialized with zero 5 value. The spin-up procedure is finished when the difference of water storage between the 1st January 1987 and the 1st January 1986 is less than $5 \%$ for more than $95 \%$ of the whole grid cells. For T2, we use the TRIP 1.0 version in the beginning to initialize the value of annual mean discharge required by Eq. (14).

River slope $s$, which is not required in T1, plays an important role in T2 (see Eq. 15). $10 S$ is calculated from the 1 degree digital elevation and the drainage flow direction maps created by Oki and Sud (1998). However as consequence of the corrections which were applied to create a more realistic flow direction map, there are many grid points having negative slope values due to the fact that the downstream points have higher elevation. We thus generally set a minimum river slope value of $10^{-6} \mathrm{~m} \mathrm{~m}^{-1}$ (i.e. $0.1 \mathrm{~m}$ per $100 \mathrm{~km}$ ) to avoid those irregular points.

In both $\mathrm{T} 1$ and $\mathrm{T} 2$, we set the meandering value, $r_{M}$ to 1.4 globally. For simplicity reason, and for avoiding the inconsistency among the GSWP2 models in the partition of total runoff into surface and subsurface components, the groundwater mode is switched off (i.e. $T_{g}=0$ ). Time step of the simulation is set to 6-hourly.

20 The sensitivity of river discharge simulated by TRIP to all the above parameters/model settings will be discussed in our further paper.

\section{Results}

\subsection{Over the mekong}

The Mekong River is the 12th longest river in the world, runs $4800 \mathrm{~km}$ from its head25

\footnotetext{
waters on the Tibetan Plateau through Yunnan Province of China, Burma, Thailand, Cambodia, Lao and Vietnam. Lancang is the name for the river's 2160-km upper and
}

\section{HESSD}

4, 4389-4414, 2007

\section{A variable velocity method for global river routing model}

T. Ngo-Duc et al.

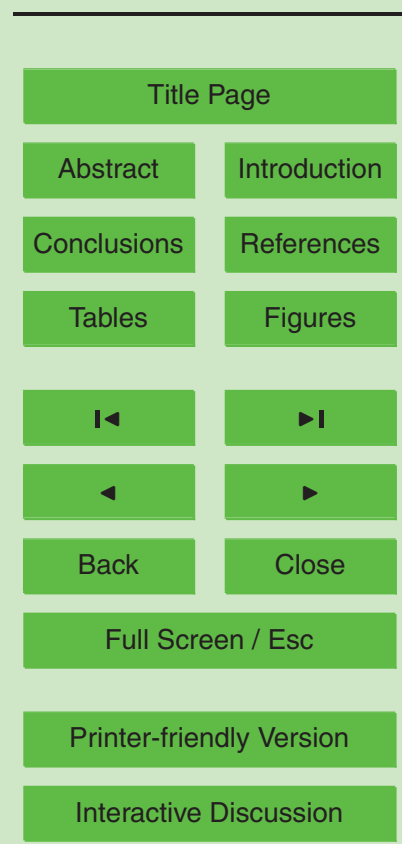

EGU 
middle reaches running through China, while the lower reaches outside China are known as the Mekong. From 1986 onwards, China began to build eight hydroelectric dams and two reservoirs on the waterway in Yunnan, where the Lancang traverses more than $1000 \mathrm{~km}$, to lift the backward western region out of poverty. The first dam at

5 Manwan, was finished in June 1995. While the GSWP2-period is for 1986-1995, our result would not be affected by the dam's operations.

In this section, we will access the quality of T1 and T2 over the Mekong by comparing the simulated and observed river discharges.

The river discharge observations used in this study are the daily data obtained from 10 the Global Runoff Data Center (GRDC). In the GRDC data, there are 12 stations over the Mekong. However, only 6 of them overlap the GSWP2 simulation period (19861995). The 3 stations Nong Khai, Near Vieanntiane and Chiang Khan are closely located (or coincide) on the 1 degree flow direction map created by Oki et al. (1998). We use thus the most downstream station, NongKhai, among those 3 stations. Then, 15 the stations over the Mekong which are used to validate our simulation results are: Luang Prabang, NongKhai, Mukdahan, Pakse (see Table 1 and Fig. 2).

Figure 3 represents a time-series comparison of river discharge for T1, T2 and the observations over the year 1990. The average upstream velocity variations simulated by T2 are also displayed in Fig. 3. In the high flow season, T2 shows that flow velocity 20 can reach to $3 \mathrm{~m} \mathrm{~s}^{-1}$ while this value is only about $1 \mathrm{~m} \mathrm{~s}^{-1}$ in the low flow season. Variable streamflow velocity allows a quick response of river discharge to a high precipitation event in the upstream region. T2 is thus able to capture the short term fluctuations (in this study is daily fluctuations) of river discharge over the Mekong.

Figure 4 displays a Taylor diagram which shows errors of simulated river discharges 25 for T1 (black filled circles) and T2 (white filled circles). A Taylor diagram (Taylor, 2001) provides the ratio of standard deviation as a radial distance and the correlation with observations as an angle in the polar plot. Each circle corresponds to the quality of simulated discharge at a predefined station. The observed discharge is represented by a point on the horizontal axis (zero correlation error) at unit distance from the origin

HESSD

4, 4389-4414, 2007

A variable velocity method for global river routing model

T. Ngo-Duc et al.

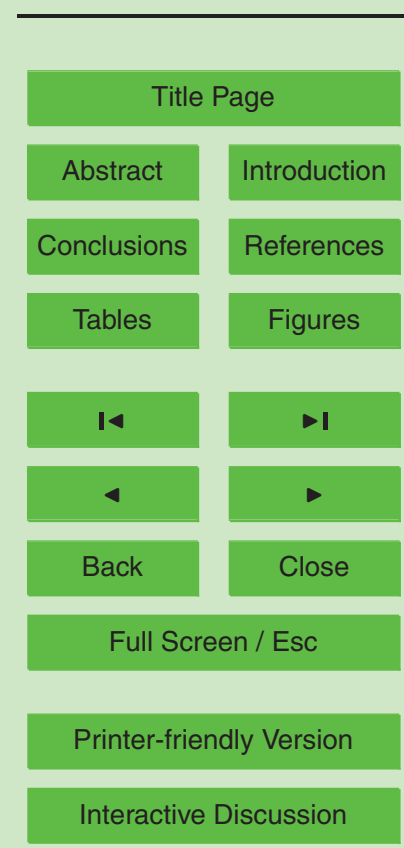

EGU 
(no error in standard deviation). In this representation the linear distance between each simulation result and observed discharge is proportional to the root mean square error (RMSE). Only the overlap period between simulations and observations is used to compute statistics.

$5 \quad$ For the 4 stations Luang Prabang, Nong Khai, Mukdahan, Pakse, a clear improvement of T2 compared to T1 is shown. T2 has smaller RMSE comparing to T1. Particularly the correlations with the observations are well improved, from an average value of 0.78 for $\mathrm{T} 1$ to an average value of more than 0.93 for $\mathrm{T} 2$.

\subsection{Over the world's largest rivers}

10 The objective of this section is to compare T2 with T1 for other rivers of the world. From the GRDC daily discharge data, 20 stations in 20 major rivers (see Table 2 and Fig. 5) were selected and compared with the simulated discharges. The stations were chosen according to the following criteria:

- Stations which have upstream drainage area greater than $300000 \mathrm{~km}^{2}$.

- Stations with a minimum observed period of 4 y which overlaps the GRDC 19861995 period.

- The most downstream station (i.e. maximum upstream drainage area) among the available ones on a river which fit the 2 above conditions.

Table 2 represents the stations used for comparing T1 and T2. The correlation $\left(r^{2}\right)$ 20 and normal standard deviation (std) between simulated and observed discharges are also displayed in Table 2. Over the period used for comparing, T2 is not statistically better than $\mathrm{T} 1$ for most of studying rivers. For some rivers (e.g. the Amazon, Ob, Kolyma), both $r^{2}$ and std of T2 are worse than those of T1. For some others (e.g. the Mississippi, Amur, Indigirka), std of T2 is better but $r^{2}$ is worse or vice-versa. For the

\section{A variable velocity method for global river routing model}

T. Ngo-Duc et al.

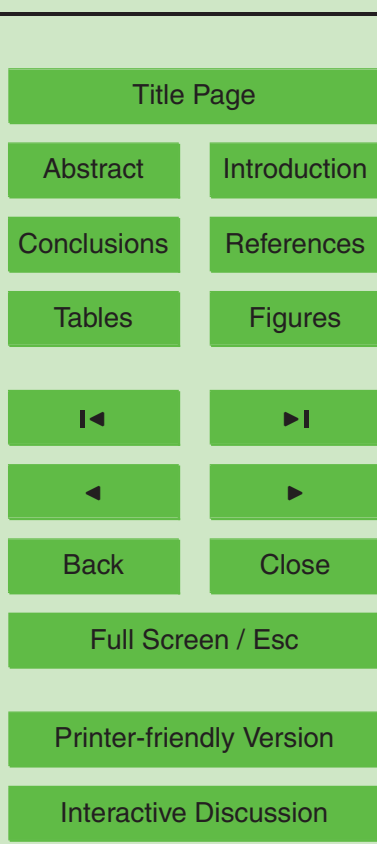

EGU 
Figure 6 shows daily time-series discharges of T1 and T2 compared to the observations at the 20 studying stations, over the two year 1987-1988. Over the stations where sub-monthly fluctuations are observed (e.g. the Mississippi, Danube, Brahmaputra, Mekong), T2 shows advantages over T1. Changing river velocity in T2 allows 5 river discharge to vary quickly, which in consequence make T2 be able to represent the sub-monthly observed discharge fluctuations. Over some stations where there are no clear short term fluctuations of river discharge, T2 seems to over-estimate those fluctuations (e.g. over the Amazon, the Orinoco). For the Niger and the Chari in Africa and some other rivers such as the Columbia, the simulated discharges are practically 0 un-correlated with the observations. The reason can be attributed to the GSWP2 precipitation quality over those basins and the fact that TRIP does not represent the natural dissipation of water from river channels to surrounding land, water used by the cities, irrigation and dam construction (Ngo-Duc et al., 2005; Hanasaki et al., 2006).

\section{Discussion}

15 One can notice that the simulated discharge however is still significantly different from the observations. Understanding the reasons for which such differences occur is important for further study and further development of the routing model. We divide the sources of errors into two main categories, errors originate from the input runoff forcing data and errors originate from the river routing models itself.

20 The first one is the error due to the input runoff forcing data. In this study, we use the multi-model runoff product from GSWP2. Each LSM participated to GSWP2 has its own approach for calculating runoff. Therefore the runoff can be quite different from one model to another. Gao and Dirmeyer (2006) has compared the GSWP2-MMA products with in-situ soil moisture observation from the Global Soil Moisture Data Bank 25 (Robock et al., 2002) and found that GSWP2-MMA is better than the best individual model at any location in the representation of both soil wetness and its anomaly. For runoff, no such study has been done yet.
HESSD

4, 4389-4414, 2007

A variable velocity method for global river routing model

T. Ngo-Duc et al.

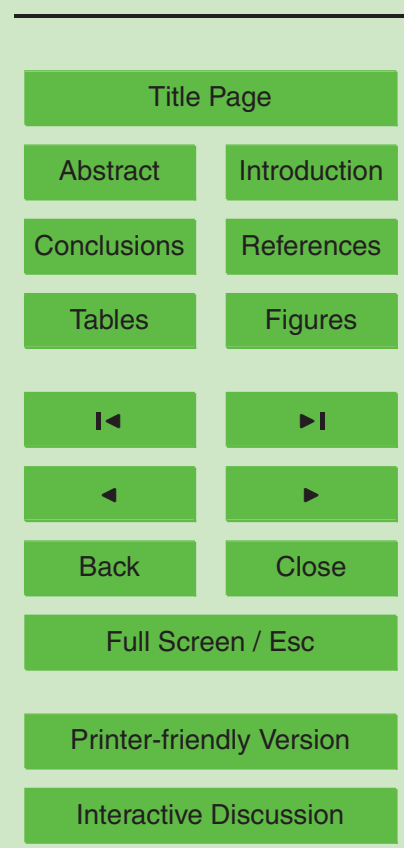

EGU 
Runoff quality depends also on the input precipitation of the LSMs (Oki et al., 1999; Ngo-Duc et al., 2005). Nevertheless, the accuracy and reliability of the 10-y GSWP2 atmospheric forcing remain questionable. Decharme and Douville (2006) showed that the baseline GSWP2 precipitation forcing is generally overestimated over the mid and 5 high latitudes, which implies systematic errors in the simulated discharges.

The second source of errors origins from the global river routing model. TRIP contains several parameterizations and several assumptions as well as it neglects certain river processes. In the numerical experiments used in this study, TRIP doesn't take into account the groundwater reservoirs. The current version of TRIP also does not rep10 resent the natural dissipation of water from river channels to surrounding land, water used by the cities, irrigation and dam construction.

In T2, drainage flow direction map is used together with the elevation map. Oki and Sud (1998) have created the 1 degree flow direction map from the 1 degree digital elevation map and have applied several corrections (including manual correction in comparison with river pathways available in the atlases). They therefore obtained a more realistic map of flow direction. However as consequence of the corrections, there are many grids points on the 1 degree map having negative slope value due to the fact that the downstream points have higher elevation (see Fig. 7). This suggests a further study of adjusting the digital elevation map to fit the new flow direction map or further simulations using some new global hydrological datasets recently available (e.g. HydroSHEDS by Lehner et al., 2006). In T2, at those irregular points, we use a minimum slope of $10^{-6} \mathrm{~m} \mathrm{~m}^{-1}$ instead of the negative values.

Other reasons of errors which come from TRIP can also be listed here: (a) Eq. (2) and Eq. (14) using in this study are empirical equations obtained for certain rivers and may not be appropriate for everywhere; (b) the meandering value of river is set to 1.4 globally, although it is 1.3 for rivers with areas larger than $500000 \mathrm{~km}^{2}$ (Oki and Sud, 1998); (c) the assumption of constant velocity during each time step in order to solve Eq. (10) may also be too rude.

The sensitivity of river discharge to different above factors (minimum slope value,
HESSD

4, 4389-4414, 2007

A variable velocity method for global river routing model

T. Ngo-Duc et al.

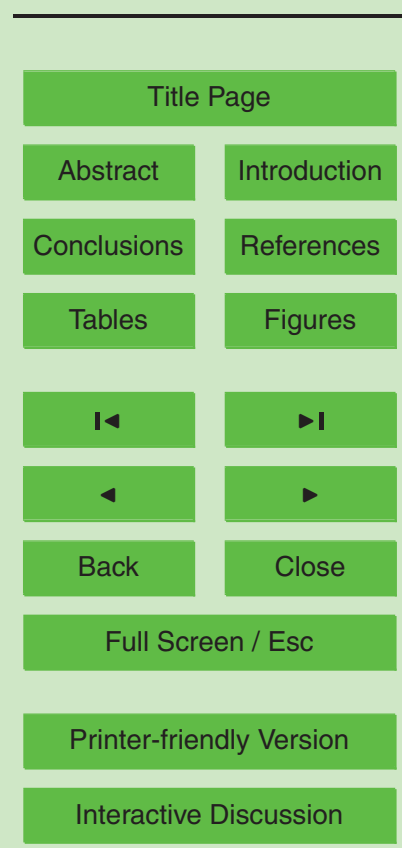

EGU 
empirical equation, meandering coefficient, etc.) would deserve another careful study in the near future.

HESSD

4, 4389-4414, 2007

\section{Conclusions}

This study was aimed at constructing a new version of the global river routing model 5 TRIP, based on a variable streamflow velocity approach, in order to simulate shorter time scale fluctuations of river discharge globally. We have used the Dingman and Sharma (1997) equation to represent the relation between river discharge and river geomorphology. Two numerical experiments, T1 obtained with the previous model version TRIP 1.0 and T2 obtained with TRIP 2.0 have been performed. The river 10 discharges simulated $\mathrm{T} 1$ and $\mathrm{T} 2$ were used to compare with the daily observations from GRDC for the world's 20 large rivers.

It was shown that, T2 has clear advantages over T1 in representing the short-term fluctuations of river discharges over certain rivers such as the Mekong, the Brahmaputra, the Mississippi, and the Danube. For the rivers where short-term fluctuations of 15 discharge are not clear, T2 is not better than T1. The differences between simulations by TRIP and GRDC observations have been attributed to several sources of errors: errors from the input forcing data and errors from the models itself. A sensitivity study which helps to quantify how much river discharge depends on those factors would be done in the near future.

TRIP 2.0 is a very first step which allows river routing model to represent short-term fluctuations of river discharge at global scale. On the technical side, input and output of TRIP 2.0 are in netCDF format. TRIP 2.0 can be configured to run with different resolutions and can also be extracted to run for only one region of interest in order to economize computer time consuming. More technical information about TRIP 2.0 can

\section{A variable velocity method for global river routing model}

T. Ngo-Duc et al.

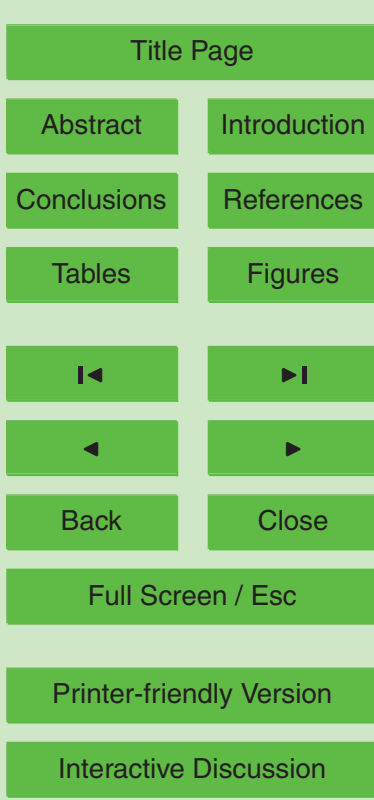

EGU 


\section{HESSD}

\section{References}

Arora, V. K. and Boer, G. J.: Effects of simulated climate change on the hydrology of major river basins, J. Geophy. Res., 106(D4), 3335-3348, 2001.

5 Arora, V. K. and Boer, G. J.: A variable velocity flow routing algorithm for GCMs, J. Geophy. Res., 104 (D24), 30 965-30 979, 1999.

Coe, M.: A linked global model of terrestrial hydrologic processes: Simulation of modern rivers, lakes and wetlands, J. Geophys. Res., 103, 8885-8899, 1998.

Dingman S. L. and Sharma K. P.: Statistical development and validation of discharge equations for natural channels, J. Hydrol., 1(199),13-35, 1997.

Dirmeyer, P. A., Gao, X., Zhao, M., Guo, Z., Oki, T., and Hanasaki, N.: The Second Global Soil Wetness Project (GSWP-2), Multi-model analysis and implications for our perception of the land surface, B. Am. Meteorol. Soc., 87(10),1381-1397, 2006.

Decharme, B. and Douville, H.: Uncertainties in the GSWP-2 precipitation forcing and their impacts on regional and global hydrological simulations, Clim. Dyn., 27, 695-713, doi:10.1007/s00382-006-0160-6, 2006.

Ducharne, A., Golaz, C., Leblois, E., Laval, K., Polcher, J., Ledoux, E., and de Marsily, G.: Development of a high resolution runoff routing model: calibration and application to assess runoff from the LMD GCM, J. Hydrol., 280, 207-228, 2003.

Fread, D. L.: Flow Routing, in Handbook of Hydrology, edited by Maidment, D. R., McGraw-Hill, New York, pp. 10.1-10.36, 1993.

Gao, X. and Dirmeyer, P. A.: Multi-model analysis, validation, and transferability study for global soil wetness products, J. Hydrometeorol., 7(6), 1218-1236, 2006.

Hagemann, S. and Dümenil, L.: A parameterization of lateral water flow for the global scale, Clim. Dyn., 14, 17-41, 1998.

Hanasaki, N., Kanae, S., and Oki, T.: A reservoir operation scheme for global river routing models, J. Hydrol., 327, 22-41, 2006.

Lehner, B., Verdin, K., and Jarvis, A.: HydroSHEDS Technical Documentation. World Wildlife Fund US, Washington, DC, available at http://hydrosheds.cr.usgs.gov , 2006.
4, 4389-4414, 2007

\section{A variable velocity method for global river routing model}

T. Ngo-Duc et al.

Title Page

Abstract

Introduction

Conclusions

References

Tables

Figures

14

$\rightarrow$

4

Back

Close

Full Screen / Esc

Printer-friendly Version

Interactive Discussion 
International GEWEX Project Office: GSWP-2: The Second Global Soil Wetness Project Science and Implementation Plan, IGPO Publication Series No. 37, 65 pp., 2002.

Maidment, D. R.: Handbook of Hydrology, McGraw-Hill,ISBN 0070397325/9780070397323, 1424 pp., 1993.

5 Miller, J. R., Russell, G. L. and Caliri, G.: Continental-scale river flow in climate models, J. Clim., 7, 914-928, 1994.

Milly, P. C. D., Dunne, K. A., and Vecchia, A. V.: Global pattern of trends in streamflow and water availability in a changing climate, Nature, 438(7066), 347-350, 2005.

New, M., Hulme, M., and Jones, P.: Representing twentieth-century space-time climate variability. Part II: Development of a 1901-1990 mean monthly grids of terrestrial surface climate, J. Clim., 13, 2217-2238, 2000.

Ngo-Duc, T., Polcher, J., and Laval, K.: A 53-year forcing data set for land surface models, J. Geophys. Res., 110, D06116, doi:10.1029/2004JD005434, 2005.

Oki, T. and Sud, Y. C.: Design of Total Runoff Integrating Pathways (TRIP) - A global river channel network. Earth Interactions 2., available at http://EarthInteractions.org, 1998.

Oki, T., Nishimura, T., and Dirmeyer, P.: Assessment of annual runoff from land surface models using total runoff integrating pathways (TRIP),J. Meteorol. Soc. Jpn., 77, 235-255, 1999.

Oki, T. and Kanae, S.: Global Hydrologic Cycle and World Water Resources, Science, 313, 5790, 1068-1072, doi:10.1126/science.1128845, 2006.

20 Polcher, J., Cox, P., Dirmeyer, P., Dolman, H., Gupta, H., Henderson-Sellers, A., Houser, P., Koster, R., Oki, T., Pitman, A., and Viterbo, P.: GLASS - Global Land-Atmosphere System Study, GEWEX News, 10(2), 3-5, 2000.

Robock, A., Vinnikov, K. Y., Srinivasan, G., Entin, J. K., Hollinger, S. E., Speranskaya, N. A., Liu, S., and Namkhai, A.: The Global Soil Moisture Data Bank, Bull. Am. Meteorol. Soc., 81, 1281-1299, 2000.

Schulze, K., Hunger, M., and Döll, P.: Simulating river flow velocity on global scale, Adv. Geosci., 5, 133-136, 2005,

http://www.adv-geosci.net/5/133/2005/.

Taylor, K. E.: Summarizing multiple aspects of model performance in a single diagram, J. Geophys. Res., 106, 7183-7192, 2001.

Wang, X., Stone, P. H., and Marotzke, J.: Global thermohaline circulation, part I, Sensitivity to atmospheric moisture transport, J. Clim., 12, 71-82, 1999.

Wijffels, S. E., Scimtt, R. W., Bryden, H. L., and Stigebrandt, A.: On the transport of freshwater

HESSD

4, 4389-4414, 2007

\section{A variable velocity method for global river routing model}

T. Ngo-Duc et al.

Title Page

Abstract

Introduction

Conclusions

References

Tables

Figures

14

$\rightarrow$

4

Back

Close

Full Screen / Esc

Printer-friendly Version

Interactive Discussion 
by the oceans, J. Phys. Oceanogr., 22, 155-162, 1992.

\section{HESSD}

4, 4389-4414, 2007

\section{A variable velocity method for global river routing model}

T. Ngo-Duc et al.

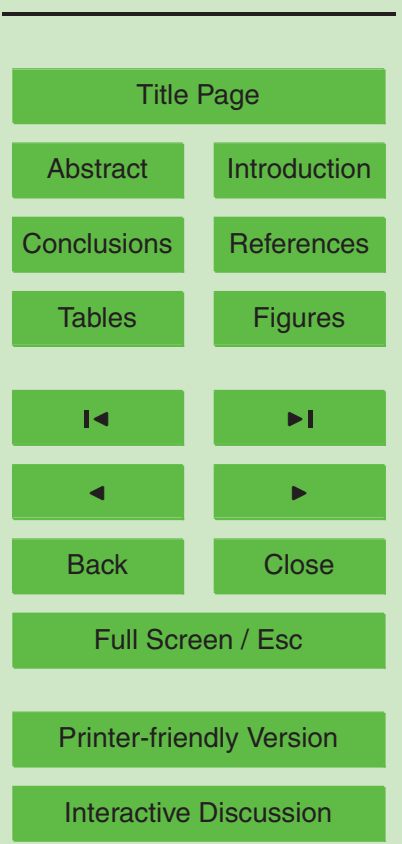




\section{HESSD}

4, 4389-4414, 2007

\section{A variable velocity method for global river routing model}

T. Ngo-Duc et al.

Table 1. GRDC stations over the Mekong, which have observations overlapping the period of GSWP2 simulations. The station ID defined by GRDC, the name, the localizations (country, longitude, Lon, and latitude, Lat), the drainage area (given by GRDC) and the discharge observation period at each station are given.

\begin{tabular}{lllllll}
\hline GRDC-No & Station & Country & Lat $\left({ }^{\circ} \mathrm{N}\right)$ & Lon $\left({ }^{\circ} \mathrm{E}\right)$ & Area $\left(\mathrm{km}^{2}\right)$ & Period \\
\hline 2469050 & Luang Prabang & Laos & 19.5 & 101.5 & 268000 & $86-93$ \\
2969090 & Nong Khai & Thailand & 17.5 & 102.5 & 302000 & $86-93$ \\
2969100 & Mukdahan & Thailand & 16.5 & 104.5 & 391000 & $86-93$ \\
2469260 & Pakse & Laos & 15.5 & 105.5 & 545000 & $86-93$ \\
\hline
\end{tabular}

Title Page

Abstract

Introduction

Conclusions

References

Tables

Figures

14

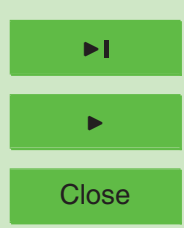

Back

Close

Printer-friendly Version

Interactive Discussion 


\section{HESSD}

\section{4, 4389-4414, 2007}

Table 2. The world's 20 rivers which have daily discharge observations during the GSWP2period (1986-1995). The approximate river length, the name, the station ID defined by GRDC, the drainage area (given by GRDC and by the TRIP river network), the localizations (longitude, Lon, and latitude, Lat) and the discharge observation period at each basin downstream station are given. Correlation $\left(r^{2}\right)$ and normal standard deviation (std) between the simulations and the observations are also displayed on the Table.

\begin{tabular}{|c|c|c|c|c|c|c|c|c|c|c|c|}
\hline & River & Station & GRDC-ID & $\begin{array}{l}\text { Lon } \\
\left({ }^{\circ} \mathrm{N}\right)\end{array}$ & $\begin{array}{l}\text { Lat } \\
\left({ }^{\circ} \mathrm{E}\right)\end{array}$ & $\begin{array}{r}\text { Drainage area } \\
\qquad\left(\mathrm{km}^{2}\right)\end{array}$ & Period & $r^{2}-\mathrm{T} 1$ & $r^{2}-\mathrm{T} 2$ & std-T1 & std-T2 \\
\hline 1 & Amazon & Obidos & 3629000 & -55.5 & -2.5 & 4640300 & $86-95$ & 0.91 & 0.63 & 1.20 & 1.33 \\
\hline 2 & Mississippi & Vicksburg & 4127800 & -91.5 & 32.5 & 2964255 & $86-95$ & 0.81 & 0.88 & 1.69 & 2.08 \\
\hline 3 & $\mathrm{Ob}$ & Salekhard & 2912600 & 66.5 & 66.5 & 2949998 & $86-95$ & 0.85 & 0.11 & 2.38 & 3.13 \\
\hline 4 & Yenisei & Igarka & 2909150 & 86.5 & 67.5 & 2440000 & $86-95$ & 0.78 & 0.49 & 0.84 & 0.87 \\
\hline 5 & Lena & Kusur & 2903420 & 127.5 & 70.5 & 2430000 & $86-94$ & 0.74 & 0.56 & 0.57 & 0.69 \\
\hline 6 & Amur & Komsomolsk & 2906900 & 137.5 & 50.5 & 1730000 & $86-90$ & 0.73 & 0.54 & 0.77 & 0.92 \\
\hline 7 & Mackenzie & Arctic red river & 4208025 & -133.5 & 67.5 & 1660000 & $86-95$ & 0.87 & 0.57 & 0.79 & 0.87 \\
\hline 8 & Volga & Volgograd Power Plant & 6977100 & 44.5 & 48.5 & 1360000 & $86-95$ & 0.66 & 0.60 & 3.11 & 3.91 \\
\hline 9 & Orinoco & Puente Angostura & 3206720 & -63.5 & 8. 5 & 836000 & $86-89$ & 0.92 & 0.79 & 0.94 & 1.00 \\
\hline 10 & Yukon & Pilot station & 4103200 & -162.5 & 61.5 & 831390 & $86-95$ & 0.85 & 0.60 & 2.28 & 2.90 \\
\hline 11 & Danube & Ceatal Izmail & 6742900 & 28.5 & 45.5 & 807000 & $86-89$ & 0.73 & 0.68 & 2.34 & 2.64 \\
\hline 12 & Niger & Niamey & 1234150 & 2.5 & 13.5 & 700000 & $86-95$ & 0.75 & 0.46 & 8.41 & 10.38 \\
\hline 13 & Brahmaputra & Bahadurabad & 2651100 & 89.5 & 25.5 & 636130 & $86-91$ & 0.82 & 0.88 & 0.69 & 0.78 \\
\hline 14 & Columbia & The Dalles, OR & 4115200 & -121.5 & 45.5 & 613830 & $86-95$ & 0.68 & 1.76 & 7.15 & 8.25 \\
\hline 15 & Chari & Ndjamena & 1537100 & 15.5 & 12.5 & 600000 & $86-90$ & 0.93 & 0.67 & 0.19 & 0.22 \\
\hline 16 & Mekong & Pakse & 2469260 & 105.8 & 15.12 & 545000 & $86-93$ & 0.75 & 1.18 & 0.91 & 1.32 \\
\hline 17 & Kolyma & Kolymskaya & 2998510 & 158.5 & 68.5 & 526000 & $86-95$ & 0.80 & 1.33 & 0.71 & 1.62 \\
\hline 18 & Severnaya Dvina & UST-Pinega & 6970250 & 41.5 & 64.5 & 348000 & $86-95$ & 0.88 & 0.54 & 1.85 & 2.12 \\
\hline 19 & Pechora & Oksino & 6970700 & 52.5 & 67.5 & 312000 & $86-95$ & 0.86 & 0.54 & 1.23 & 1.41 \\
\hline 20 & Indigirka & Vorontsovo & 2998400 & 147.5 & 69.5 & 305000 & $86-94$ & 0.79 & 0.53 & 0.77 & 0.93 \\
\hline
\end{tabular}

\section{A variable velocity method for global river routing model}

T. Ngo-Duc et al.

\section{Title Page}

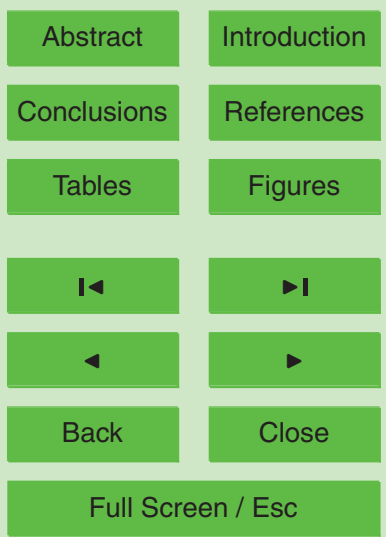

Printer-friendly Version

Interactive Discussion 


\section{HESSD}

4, 4389-4414, 2007

(a) T1

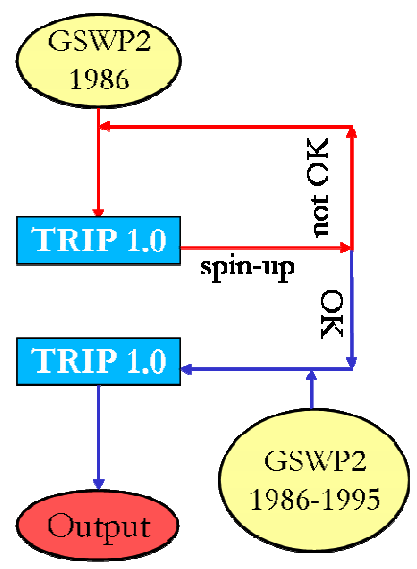

(b) T2

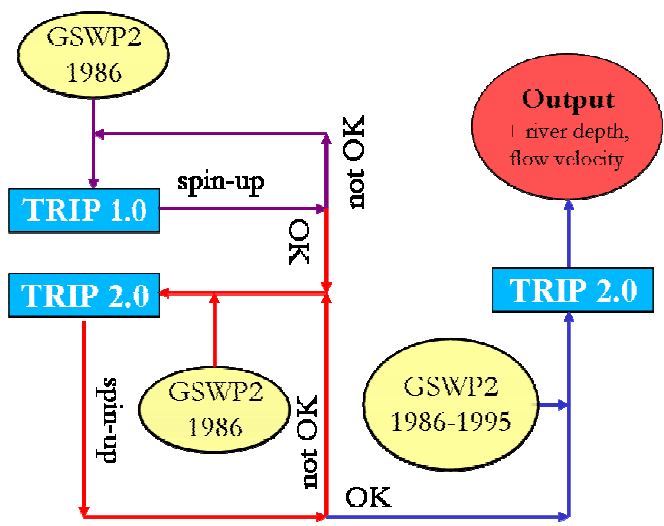

Fig. 1. Schema for (a) Constant Velocity Run (T1), (b) Variable Velocity Run (T2).

A variable velocity method for global river routing model

T. Ngo-Duc et al.

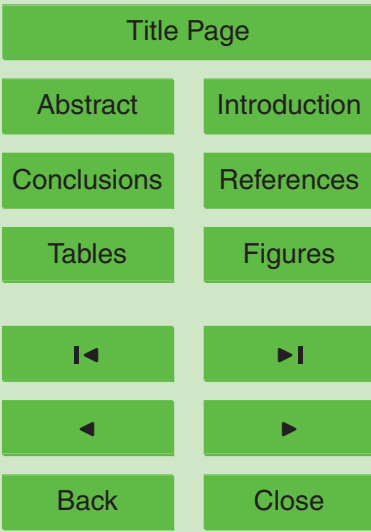

Full Screen / Esc

Printer-friendly Version

Interactive Discussion 


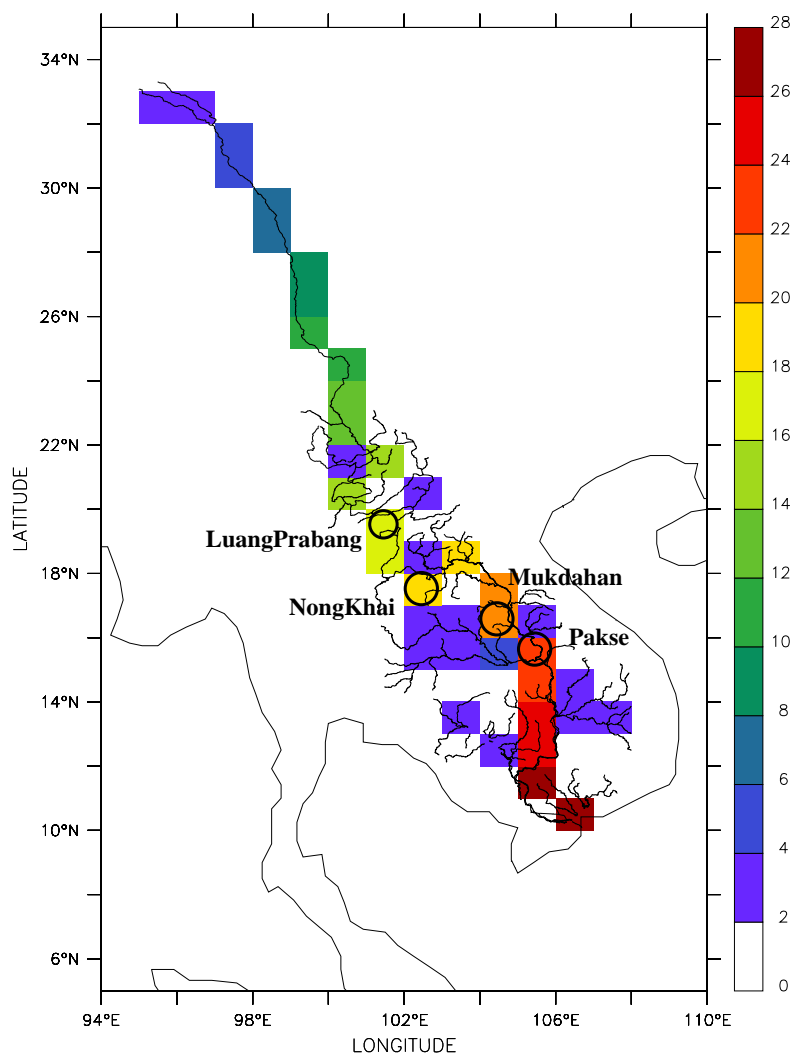

Fig. 2. 1 degree Mekong river sequence map designed by Oki et al. (1998). River information from the World Data Bank II (WDBII) developed by the U.S. Central Intelligence Agency is superimposed. The discharge stations using in this study are located by the circulars on the 1 degree resolution map.

\section{HESSD}

4, 4389-4414, 2007

A variable velocity method for global river routing model

T. Ngo-Duc et al.

\section{Title Page}

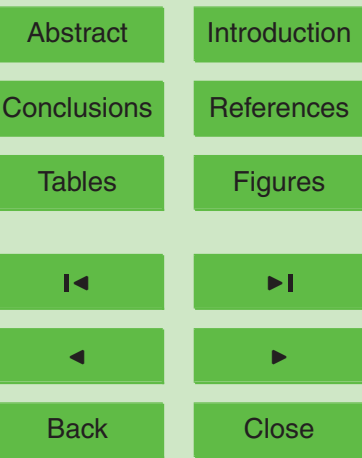

Full Screen / Esc

Printer-friendly Version

Interactive Discussion 


\section{HESSD}

4, 4389-4414, 2007
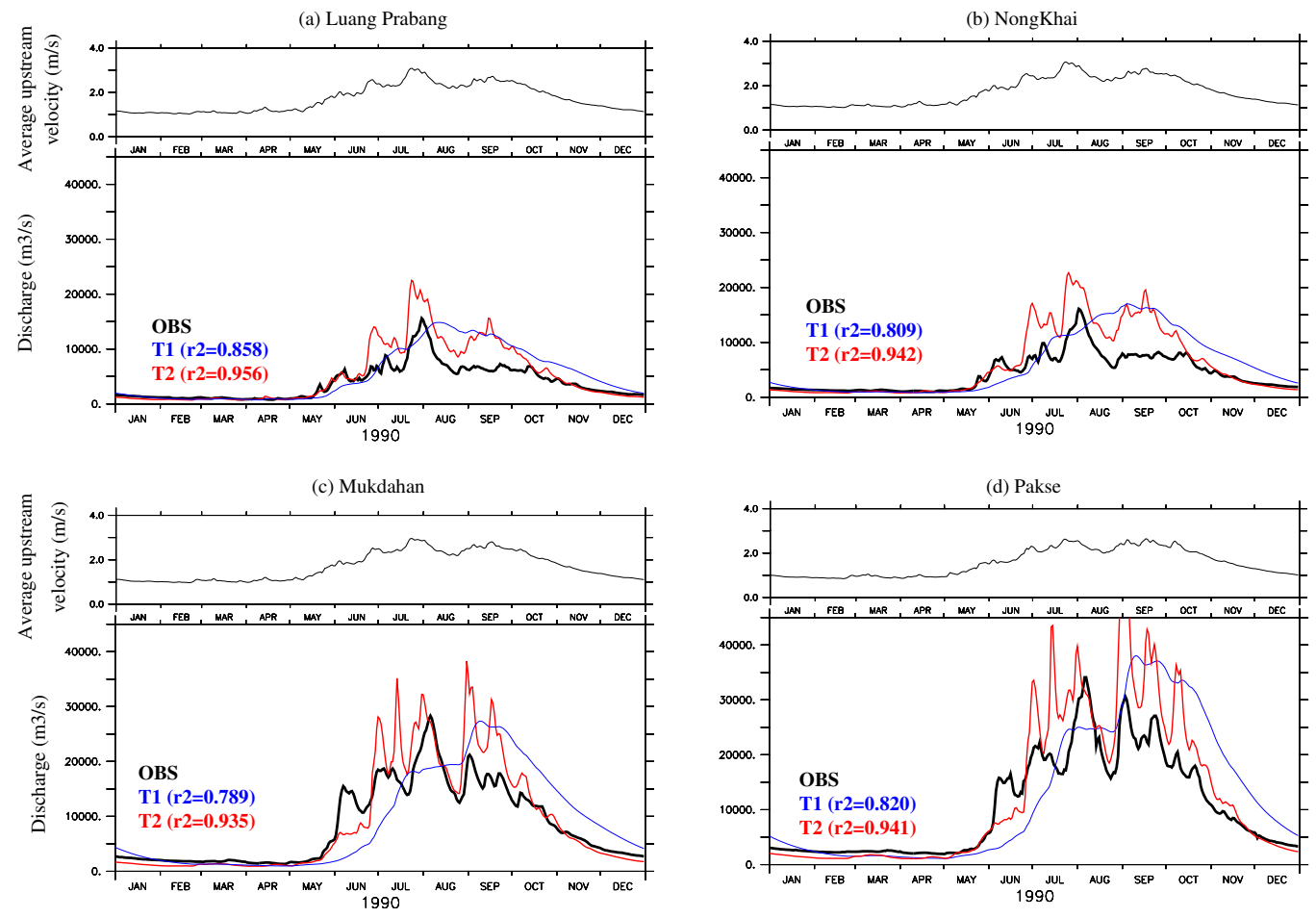

\section{A variable velocity method for global river routing model}

T. Ngo-Duc et al.

Title Page

Abstract

Introduction

Conclusions

References

Tables

Figures

14

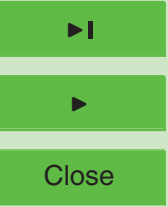

Back

Close

\section{Full Screen / Esc}

Fig. 3. River discharges simulated by T1 (blue curve), T2 (red curve) compared to the observations (black curve) at (a) Luang Prabang, (b) NongKhai, (c) Mukadahan and (d) Pakse.

Printer-friendly Version

Interactive Discussion 


\section{HESSD}

4, 4389-4414, 2007

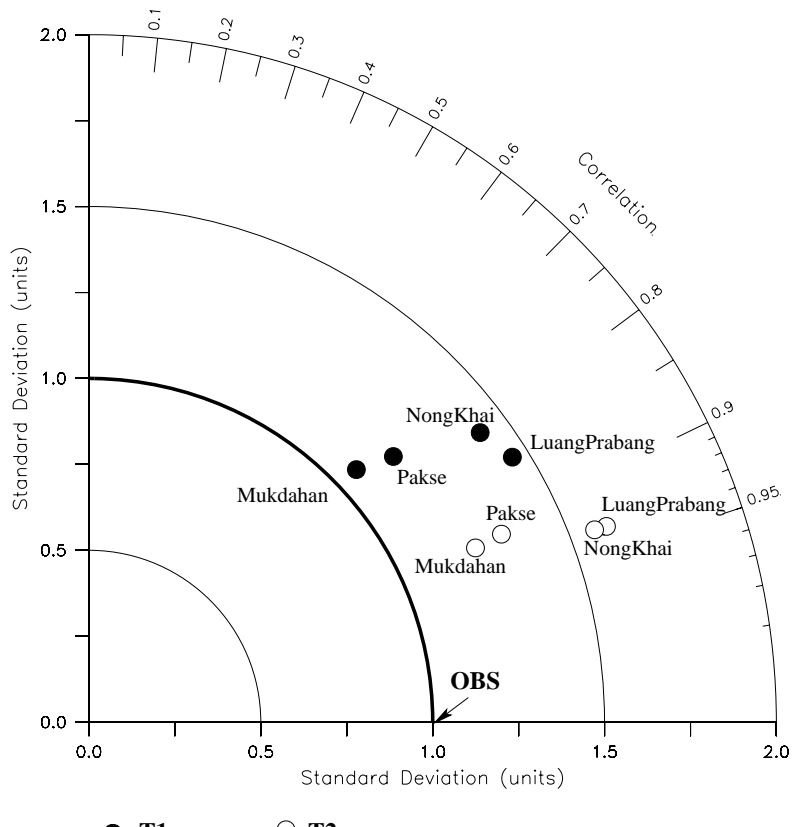

A variable velocity method for global river routing model

T. Ngo-Duc et al.

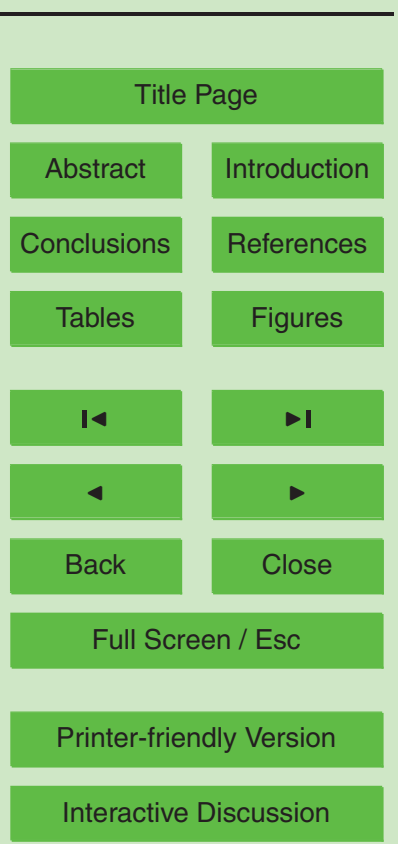

Fig. 4. Taylor diagram illustrating the statistics of simulated river discharge compared with daily observations at (a) Luang Prabang station, (b) Nong Khai station, (c) Mukdahan satation, (d) Pakse station. 


\section{HESSD}

4, 4389-4414, 2007

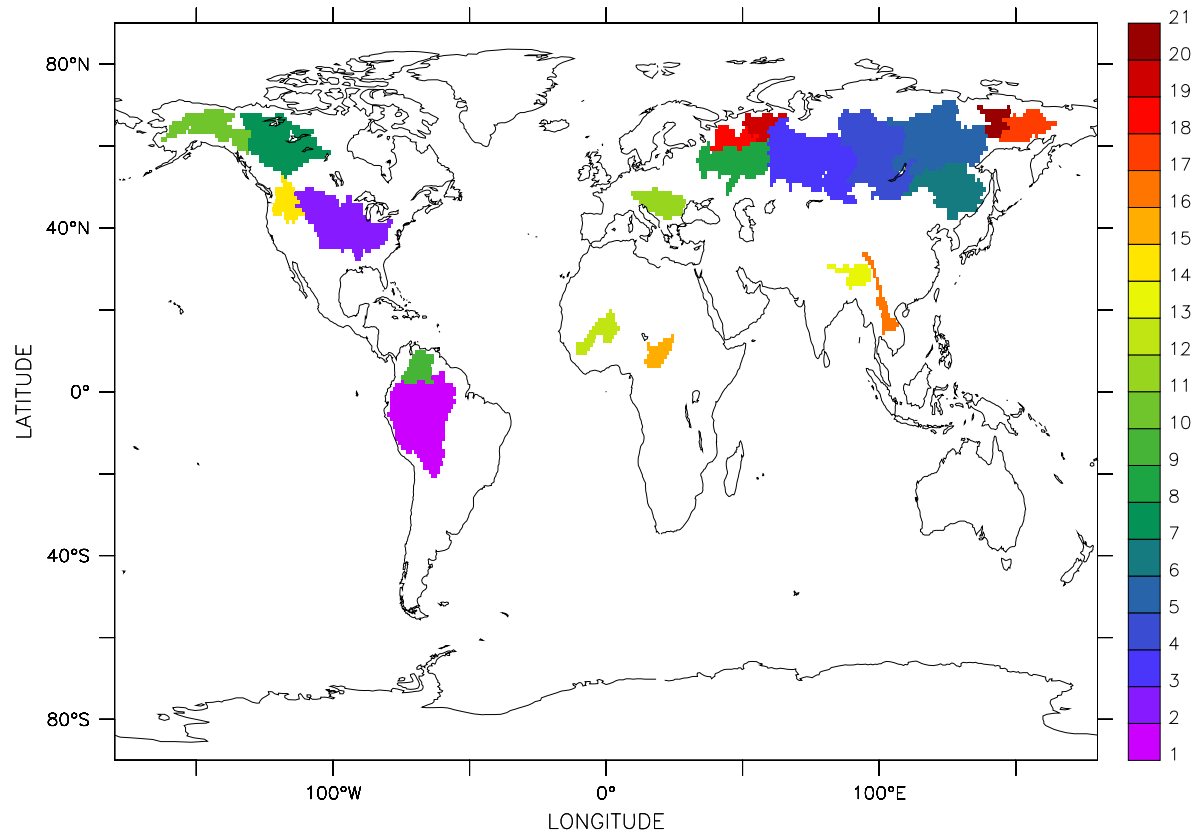

A variable velocity method for global river routing model

T. Ngo-Duc et al.

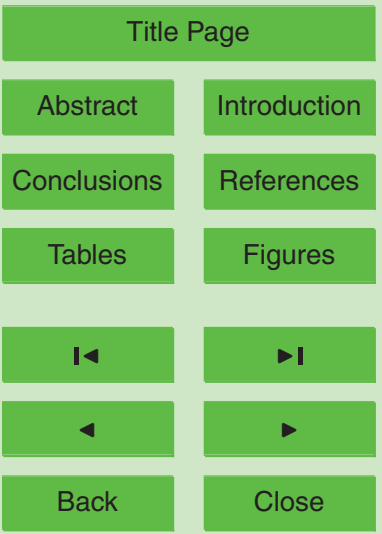

Fig. 5. Upstream of the 20 stations used in this study. Number corresponds to the number of

\section{Full Screen / Esc} river in Table 2.

Printer-friendly Version

Interactive Discussion 

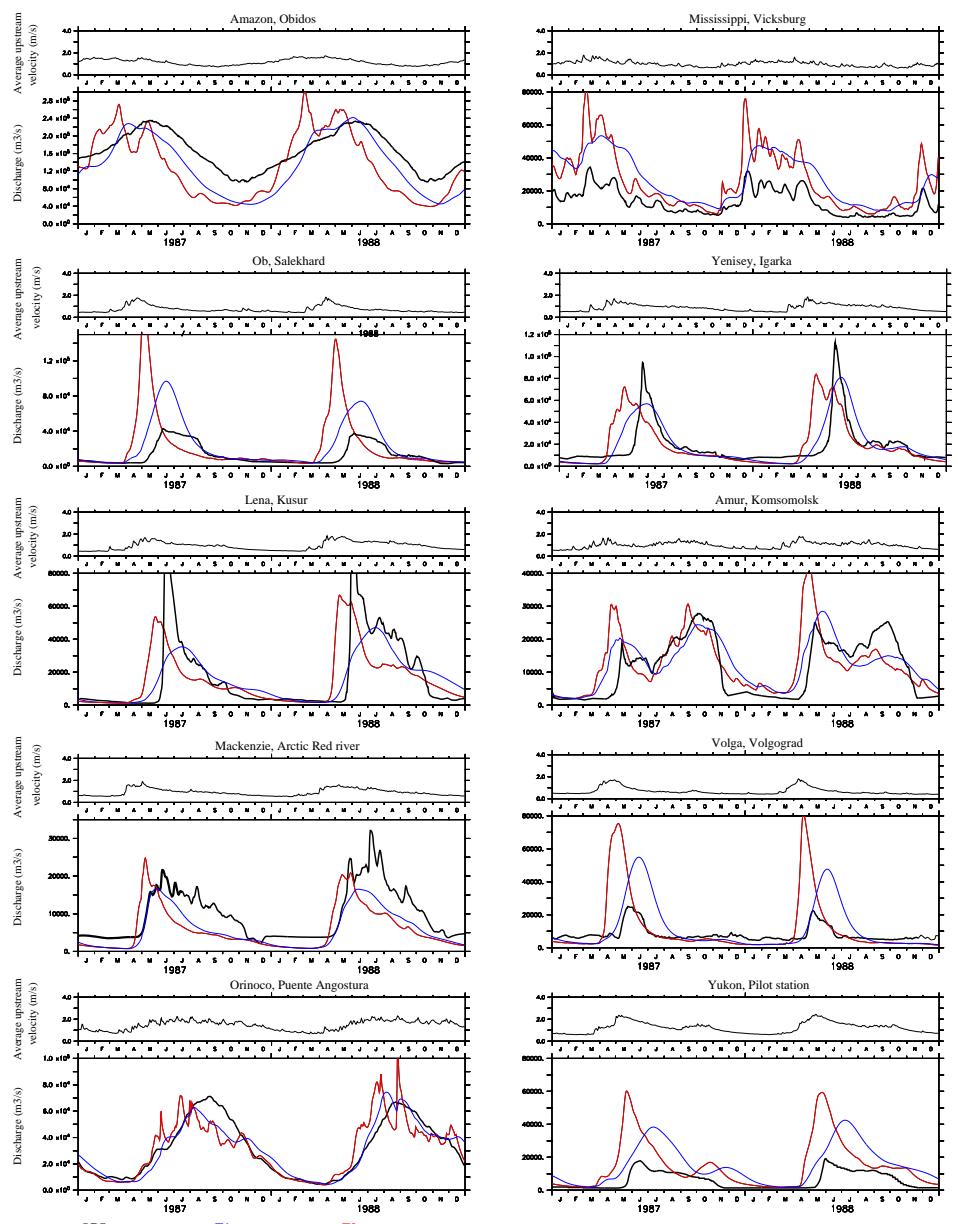

HESSD

4, 4389-4414, 2007

A variable velocity method for global river routing model

T. Ngo-Duc et al.

Title Page

Abstract

Introduction

Conclusions

References

Tables

Figures

14

4

Back

Close

\section{Full Screen / Esc}

Printer-friendly Version

Interactive Discussion

Fig. 6a. Daily discharges of T1 and T2 compared to the observations at the 20 studying stations, over the two year 1987-1988. Observations: red; T1: black; T2: blue. Unit in $\mathrm{m}^{3} \mathrm{~s}^{-1}$. 

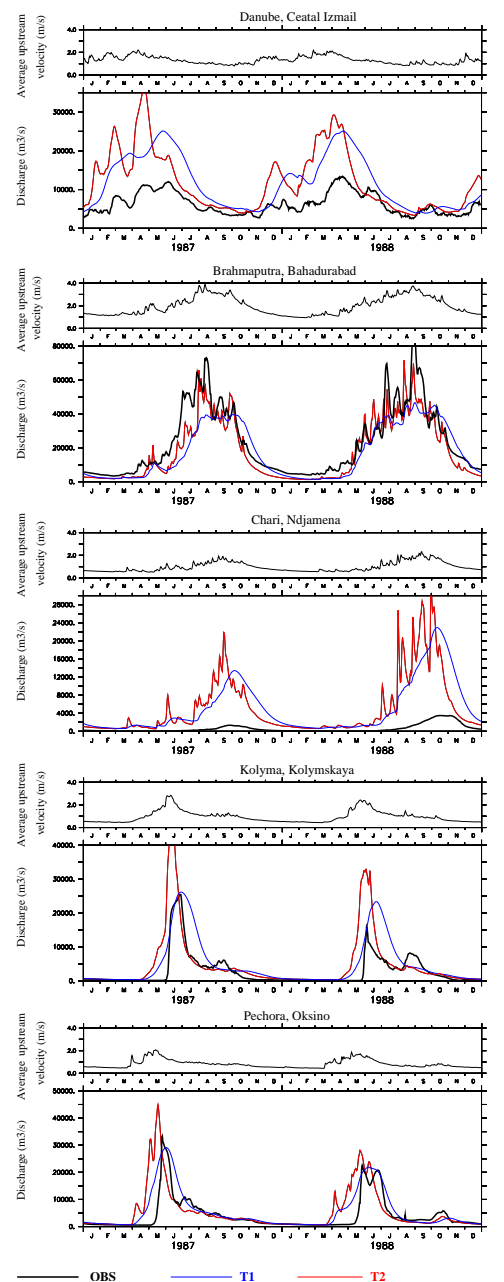

Fig. 6b. Continued.
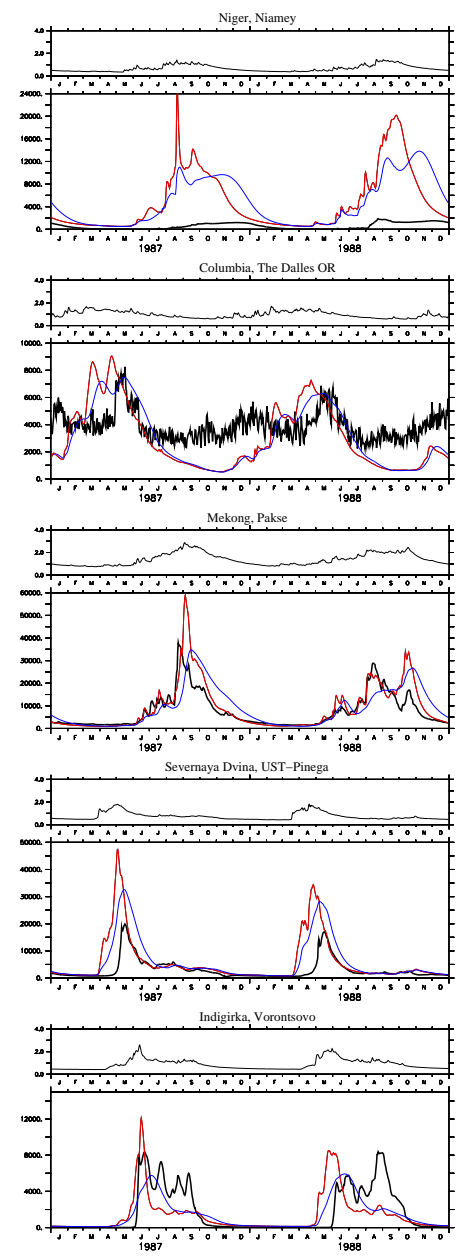

\section{Full Screen / Esc}

Printer-friendly Version

Interactive Discussion 


\section{HESSD}

4, 4389-4414, 2007

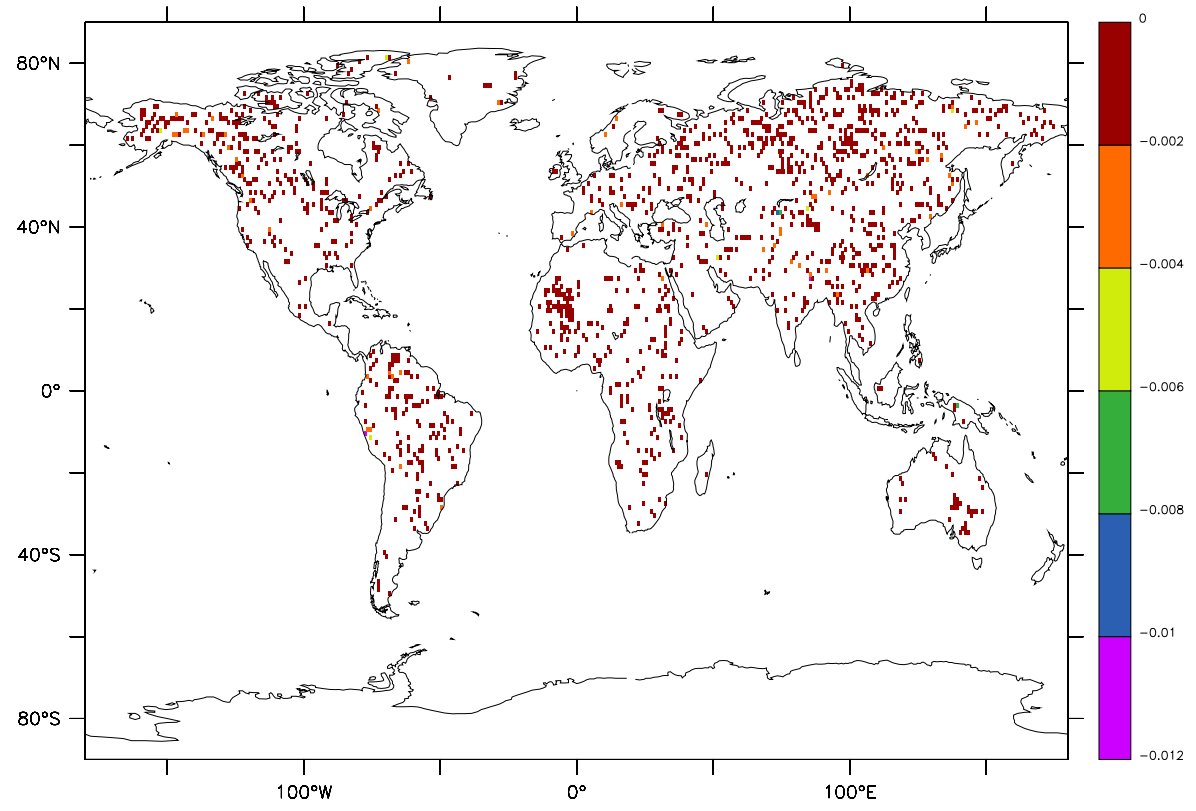

A variable velocity method for global river routing model

T. Ngo-Duc et al.

Title Page

Abstract

Introduction

Conclusions

References

Tables

Figures

14

4

Back

Close

\section{Full Screen / Esc} downstream point has higher elevation). In T2, the river slope of those points will be set to the minimum river slope value (which is positive).

Printer-friendly Version

Interactive Discussion 